Article

\title{
Neuroprotective Effects and Mechanisms of Curcumin-Cu(II) and -Zn(II) Complexes Systems and Their Pharmacological Implications
}

\author{
Fa-Shun Yan ${ }^{1,2,+} \mathbb{D}$, Jian-Long Sun ${ }^{1,2,+}$, Wen-Hai Xie ${ }^{1,2}$, Liang Shen ${ }^{1,2, *}$ and Hong-Fang Ji ${ }^{1,2, *}$ \\ 1 Institute of Biomedical Research, Shandong University of Technology, Zibo 255000, Shandong, China; \\ 18353365531@163.com (F.-S.Y.); 18369909086@163.com (J.-L.S.); xiewenhai@sdut.edu.cn (W.-H.X.) \\ 2 Shandong Provincial Research Center for Bioinformatic Engineering and Technique, School of Life Sciences, \\ Shandong University of Technology, Zibo 255000, Shandong, China \\ * Correspondence: shen@sdut.edu.cn (L.S.); jhf@sdut.edu.cn (H.-F.J.); Tel.: +86-533-278-2220 (L.S. \& H.-F.J.) \\ $\dagger$ These authors contributed equally to this work.
}

Received: 15 November 2017; Accepted: 7 December 2017; Published: 28 December 2017

\begin{abstract}
Alzheimer's disease (AD) is the main form of dementia and has a steadily increasing prevalence. As both oxidative stress and metal homeostasis are involved in the pathogenesis of AD, it would be interesting to develop a dual function agent, targeting the two factors. Curcumin, a natural compound isolated from the rhizome of Curcuma longa, is an antioxidant and can also chelate metal ions. Whether the complexes of curcumin with metal ions possess neuroprotective effects has not been evaluated. Therefore, the present study was designed to investigate the protective effects of the complexes of curcumin with $\mathrm{Cu}$ (II) or $\mathrm{Zn}$ (II) on hydrogen peroxide $\left(\mathrm{H}_{2} \mathrm{O}_{2}\right)$-induced injury and the underlying molecular mechanisms. The use of rat pheochromocytoma (PC12) cells, a widely used neuronal cell model system, was adopted. It was revealed that curcumin- $\mathrm{Cu}$ (II) complexes systems possessed enhanced $\mathrm{O}_{2}{ }^{--}$-scavenging activities compared to unchelated curcumin. In comparison with unchelated curcumin, the protective effects of curcumin-Cu(II) complexes systems were stronger than curcumin-Zn(II) system. Curcumin-Cu(II) or $-\mathrm{Zn}$ (II) complexes systems significantly enhanced the superoxide dismutase, catalase, and glutathione peroxidase activities and attenuated the increase of malondialdehyde levels and caspase- 3 and caspase- 9 activities, in a dose-dependent manner. The curcumin-Cu(II) complex system with a 2:1 ratio exhibited the most significant effect. Further mechanistic study demonstrated that curcumin-Cu(II) or - $\mathrm{Zn}$ (II) complexes systems inhibited cell apoptosis via downregulating the nuclear factor $\kappa \mathrm{B}(\mathrm{NF}-\mathrm{\kappa B})$ pathway and upregulating $\mathrm{Bcl}-2 / \mathrm{Bax}$ pathway. In summary, the present study found that curcumin- $\mathrm{Cu}$ (II) or $-\mathrm{Zn}$ (II) complexes systems, especially the former, possess significant neuroprotective effects, which indicates the potential advantage of curcumin as a promising agent against $\mathrm{AD}$ and deserves further study.
\end{abstract}

Keywords: curcumin; Alzheimer's disease; metal ions; oxidative stress; PC12 cells

\section{Introduction}

As the major form of dementia, Alzheimer's disease (AD) is a progressive and irreversible neurodegenerative disease, which is related to aging and has a steadily increasing prevalence [1-3]. Due to the considerable burden on patients, family and society, screening efficient drugs for AD is a major challenge in drug discovery. Despite much effort being devoted to drug discovery of AD over the past decades, there is no effective therapeutic drug available to treat $\mathrm{AD}$. The pathogenesis of $\mathrm{AD}$ remains far from being fully elucidated and oxidative damage to neurons caused by excessive reactive oxygen species (ROS) is widely recognized as an important factor [4-7]. Antioxidant supplement 
represents a promising strategy to combat AD. In addition, brain metal dysregulation, including copper $(\mathrm{Cu}(\mathrm{II}))$ and zinc $(\mathrm{Zn}(\mathrm{II}))$ ions, is intimately involved in the pathogenesis of AD [8-10]. The interaction of $\mathrm{Cu}(\mathrm{II})$ with both amyloid $\beta(\mathrm{A} \beta)$ peptides and the amyloid precursor protein (APP) has gained much attention in recent years [8-10]. Therefore, regulation of metal homeostasis is also considered to be a key therapeutic target. In recent years, many attempts have been made to explore metal chelators as potential agents against $\mathrm{AD}$ [11-13].

Curcumin is a yellow phenolic compound, isolated from the rhizome of turmeric (Curcuma longa), which has been intensively studied in the past decades owing to its wide spectrum of pharmacological activities, including antioxidant, anticancer, anti-inflammatory, and antimicrobial effects [14-17]. Curcumin can scavenge ROS and also chelate various metal ions [18-20]. Our previous studies found that the complexes of curcumin with metal ions possess superoxide dismutase (SOD)-like activity [21-23]. Thus, considering its abilities to scavenge free radicals and bind metal ions, curcumin may act as a promising agent to combat AD, especially in view of its good clinical safety, even at high dosage. In addition, it has been reported that curcumin can inhibit $\mathrm{A} \beta$ aggregation and fibril formation, promote the clearance of $\mathrm{A} \beta$ plaques, attenuate tau hyperphosphorylation, and inhibit acetylcholinesterase activity [24-26]. Rat pheochromocytoma (PC12) is a cell line derived from a pheochromocytoma of the rat adrenal medulla, which possesses the characteristics of neural cells and is widely used as a cell model system for neurodegenerative diseases [27-31]. With the aim of further exploring the neuroprotective effects of the metal ion complexes of curcumin and elucidating underlying mechanisms, we investigated the protective effects of curcumin and curcumin- $\mathrm{Cu}(\mathrm{II})$ or $-\mathrm{Zn}(\mathrm{II})$ complexes against hydrogen peroxide $\left(\mathrm{H}_{2} \mathrm{O}_{2}\right)$-induced injury in PC12 cells. Further mechanistic study demonstrated that curcumin-Cu(II) or - Zn(II) complexes inhibited cell apoptosis via downregulating the nuclear factor $\kappa \mathrm{B}(\mathrm{NF}-\mathrm{kB})$ and upregulating Bcl-2/Bax pathways.

\section{Materials and Methods}

\subsection{Materials}

Penicillin-streptomycin and Nutrient Mixture F-12 Ham were purchased from Sigma-Aldrich Shanghai Trading Co. (Shanghai, China). Horse serum (HS) was purchased from Solarbio Biological Technology Co., Ltd. (Beijing, China), fetal bovine serum (FBS) from Gibco (Glen Waverley, Australia). Curcumin, an extract from the turmeric powder of Curcuma longa, comprising the three main components-curcumin, demethoxycurcumin and bidemethoxycurcumin-was purchased from Shanghai Macklin Biological Technology Co., Ltd. (Shanghai, China). Copper chloride dehydrate, zinc chloride, pyrogallol, 1-(4,5dimethylthiazol-2-yl)-3,5-diphenylformazan (MTT) and $2^{\prime}, 7^{\prime}$-dichlorofluorescindiacetate (DCFH-DA) were purchased from Sigma-Aldrich Shanghai Trading Co. Ltd. (Shanghai, China). $\mathrm{H}_{2} \mathrm{O}_{2}$ was purchased from Shuangshuang Chemical Co., Ltd. (Yantai, China). The kits for the Bradford protein assay, malondialdehyde (MDA), SOD, catalase (CAT) and glutathione peroxidase (GSH-Px) activities were gained from Nanjing Jiancheng Bioengineering Institute (Nanjing, China). Annexin V-fluorescein isothiocyanate (FITC)/propidium iodide (PI) apoptosis detection kit, caspase-3 and caspase-9 activity assay kits were purchased from Bibo Biological Technology Co., Ltd. (Nanjing, China). The enhanced chemiluminescence (ECL) kit, Bcl-2, Bax, p65 and $\beta$-actin antibody was purchased from Nanjing Enogene Biotech. Co., Ltd. (Nanjing, China). All other reagents were of analytical grade.

\subsection{Superoxide Anion Radical Scavenging Assay}

The superoxide anion radical $\left(\mathrm{O}_{2}{ }^{-}\right)$-scavenging activities of curcumin and curcumin- $\mathrm{Cu}$ (II) or -Zn(II) complexes were measured with a modified pyrogallol autoxidation method [32]. Briefly, a pyrogallol solution (in $1 \mathrm{M} \mathrm{HCl}$ ) was thoroughly mixed with Tris- $\mathrm{HCl}$ buffer at $\mathrm{pH} 7.4$ and the absorption $\left(\mathrm{A}_{325 \mathrm{~nm}}\right)$ was recorded every $30 \mathrm{~s}$ for $5 \mathrm{~min}$ at $37^{\circ} \mathrm{C}$ using a microplate reader (EVOLUTION 
220, Thermo Fisher Scientific Oy, Vantaa, Finland). The $\mathrm{O}_{2}^{--}$-scavenging rate was estimated according to the following formula $(\mathrm{T}=5 \mathrm{~min})$ :

$$
\left(\frac{\Delta \mathrm{A}_{325 \mathrm{~nm}, \text { control }}}{\mathrm{T}}-\frac{\Delta \mathrm{A}_{325 \mathrm{~nm}, \text { sample }}}{\mathrm{T}}\right) / \frac{\Delta \mathrm{A}_{325 \mathrm{~nm}, \text { control }}}{\mathrm{T}} \times 100 \%
$$

The concentrations of curcumin and curcumin-Cu(II) or - $\mathrm{Zn}$ (II) complexes for $50 \% \mathrm{O}_{2}{ }^{--}$-scavenging was defined as the $\mathrm{IC}_{50}$ value.

\subsection{Cell Culture and Viability Assay}

PC12 cells, obtained from the Type Culture Collection of the Chinese Academy of Sciences (Shanghai, China), were cultured in Nutrient Mixture F-12 Ham medium, supplemented with $10 \%$ HS, $5 \% \mathrm{FBS}, 100 \mathrm{U} / \mathrm{ml}$ of penicillin and streptomycin at $37^{\circ} \mathrm{C}$ under $5 \% \mathrm{CO}_{2}$. Before treatment, $\mathrm{PC} 12$ cells were seeded in 6 or 96-well plates $\left(1\right.$ or $3 \times 10^{5}$ cells $/ \mathrm{ml}$ ) and cultured for $24 \mathrm{~h}$. Cells were pretreated with curcumin and curcumin-Cu(II) or $-\mathrm{Zn}$ (II) complexes for $0.5 \mathrm{~h}$, before adding $\mathrm{H}_{2} \mathrm{O}_{2}$. Cell viability was assessed by an MTT assay [33]. After $24 \mathrm{~h}$, the cells were incubated with $\mathrm{H}_{2} \mathrm{O}_{2}(500 \mu \mathrm{M})$ for an additional $24 \mathrm{~h}$. Finally, $20 \mu \mathrm{L}$ MTT was added to each well. After $4 \mathrm{~h}, 200 \mu \mathrm{L}$ DMSO was added to each well to dissolve the formazan crystals. The absorbance was measured at $570 \mathrm{~nm}$ using a Multiwell microplate reader (MultiskanGo, Thermo Fisher Scientific Oy, Vantaa, Finland). Cell viability was expressed as the percentage of the control group.

\subsection{ROS Assay}

The intracellular ROS level was quantified using a DCFH-DA assay. At $24 \mathrm{~h}$ after seeding, the cells were pretreated with $25 \mu \mathrm{M}$ curcumin and curcumin-Cu(II) or - Zn(II) complexes for $0.5 \mathrm{~h}$ and $500 \mu \mathrm{M} \mathrm{H}_{2} \mathrm{O}_{2}$ was added. After $6 \mathrm{~h}$ of incubation, the cells were washed with PBS (0.1 M, pH 7.4) and incubated with $10 \mu \mathrm{M}$ DCFH-DA for $0.5 \mathrm{~h}$ in the dark. After treatment, the cells were washed with serum-free medium three times, and then pictures were taken with a fluorescence microscope (Olympus IX73, Tokyo, Japan), and relative fluorescence intensity was measured with a fluorescent microplate reader (Varioskan Flash, Thermo Fisher Scientific Oy, Vantaa, Finland). The intracellular ROS level in the control group was defined as $100 \%$ and the other groups were assessed as a percentage of the control.

\subsection{Apoptosis Assay}

Cell apoptosis was measured by annexin V-FITC/PI Staining. At $24 \mathrm{~h}$ after seeding, the cells were pretreated with curcumin and curcumin- $\mathrm{Cu}$ (II) or $-\mathrm{Zn}$ (II) systems for $0.5 \mathrm{~h}$ and $\mathrm{H}_{2} \mathrm{O}_{2}$ was added. After $6 \mathrm{~h}$ of incubation, the treated cells were washed with ice-cold PBS (0.1 M, pH 7.4) twice. Cells were resuspended in mixture of $500 \mu \mathrm{L}$ of $1 \times$ binding buffer, $5 \mu \mathrm{L}$ annexin V-FITC and PI for $10 \mathrm{~min}$ in the dark, and then analyzed by a fluorescence microscope (Olympus IX73, Tokyo, Japan).

\subsection{MDA and Antioxidant Enzymes Assay}

Treatment with curcumin or curcumin-Cu(II) or $-\mathrm{Zn}$ (II) complexes on PC12 cells was same as the above assay. After $6 \mathrm{~h}$ of incubation, the treated cells were washed twice with ice-cold PBS $(0.1 \mathrm{M}, \mathrm{pH} 7.4)$ and homogenized. The homogenate was centrifuged at 12,000 rpm for $15 \mathrm{~min}$ at $4{ }^{\circ} \mathrm{C}$, and then supernatant was collected for further experiments. The MDA content was evaluated using the 2-thiobarbituric acid assay [34]. Protein content was measured by the Bradford method [35]. The levels of intracellular antioxidant enzyme, CAT, total SOD and GSH-Px activities were determined according to the manuals of assay kits (Nanjing Jiancheng Bioengineering Institute, Nanjing, China). 


\subsection{Caspase-3 and Caspase-9 Activity}

Treatment of PC12 cells with curcumin or curcumin-Cu(II) or-Zn(II) complexes was in accordance with the above assay. After $12 \mathrm{~h}$ of incubation, the treated cells were washed twice with ice-cold PBS and homogenized. The homogenate was centrifuged at $12,000 \mathrm{rpm}$ for $15 \mathrm{~min}$ at $4{ }^{\circ} \mathrm{C}$ and then the supernatant of cell lysates was collected for further experiment. The activity of caspase-3 and caspase- 9 were measured using assay kits (Nanjing Bibo Biological Technology, Nanjing, China).

\subsection{Western Blotting}

The cell lysates were centrifuged at $12,000 \mathrm{rpm}$ for $15 \mathrm{~min}$ at $4{ }^{\circ} \mathrm{C}$ and then protein was separated by sodium dodecyl sulfate-polyacrylamide gel electrophoresis and transferred to PVDF membranes, which were blocked in 5\% skim milk powder for $1 \mathrm{~h}$, and then incubated with primary antibodies overnight at $4{ }^{\circ} \mathrm{C}$. On the second day, the membrane was washed by TBST thrice, and then incubated with the secondary antibody for $1.5 \mathrm{~h}$. The membrane was developed in an ECL reagent and visualized by a chemiluminescence detection system (ChemiScope 5300, Clinx, Shanghai, China).

\subsection{Statistical Analysis}

All independent experiments were conducted in triplicate. The data were shown as the mean \pm standard deviation (SD). Statistical analysis was performed using SPSS (16.0) software (IBM Corporation, Armonk, NY, USA). The difference in the different groups was analyzed by one-way analysis of variance (ANOVA) and Tukey's multiple comparisons post-hoc test. The significance levels were defined as ${ }^{\#} p<0.01,{ }^{* *} p<0.01$ and ${ }^{*} p<0.05$.

\section{Results}

\section{1. $\mathrm{O}_{2}{ }^{--}$-Scavenging Activities}

$\mathrm{O}_{2}{ }^{--}$-scavenging activities of curcumin and curcumin-Cu(II) or $-\mathrm{Zn}(\mathrm{II})$ complexes were examined and the results are shown in Table 1. It was found that curcumin-Cu(II) complexes exhibited enhanced $\mathrm{O}_{2}{ }^{--}$-scavenging activities significantly more than parent curcumin and curcumin- $\mathrm{Zn}$ (II) complexes.

Table 1. Superoxide anion radical-scavenging activities of curcumin and the complexes. Data were expressed as the mean \pm standard deviation (SD), $n=3$. ( ${ }^{*} p<0.05$ and ${ }^{* *} p<0.01$ versus curcumin).

\begin{tabular}{cc}
\hline Compounds & IC $_{\mathbf{5 0}}(\boldsymbol{\mu M})$ \\
\hline 2:1 curcumin-Cu(II) complex & $238.14 \pm 15.83^{* *}$ \\
1:1 curcumin-Cu(II) complex & $171.86 \pm 14.86^{* *}$ \\
2:1 curcumin-Zn(II) complex & $323.49 \pm 17.31$ \\
1:1 curcumin-Zn(II) complex & $357.85 \pm 12.93^{*}$ \\
curcumin & $307.89 \pm 15.42$ \\
\hline
\end{tabular}

\subsection{Cell Viability}

Different concentrations of $\mathrm{H}_{2} \mathrm{O}_{2}$ were employed for cytotoxic tests, to build the oxidative injury model of PC12 cells. As estimated by the MTT assay, cell viability was significantly decreased to $47.3 \%$ after treatment with $500 \mu \mathrm{M} \mathrm{H}_{2} \mathrm{O}_{2}$ for $24 \mathrm{~h}$ (Figure 1A). Thus, $500 \mu \mathrm{M} \mathrm{H}_{2} \mathrm{O}_{2}$ was regarded as the oxidative injury model for the subsequent experiments. When cells were pre-incubated with curcumin $(6.25-25 \mu \mathrm{M})$ for $0.5 \mathrm{~h}$, as shown in Figure $1 \mathrm{~B}$, curcumin $(25 \mu \mathrm{M})$ showed an efficient neuroprotective effect and the cell viability increased significantly by $22.4 \%$ compared with $\mathrm{H}_{2} \mathrm{O}_{2}$-treated cells. The cytotoxicity experiment indicated no obvious reduction in cell viability with the treatment of curcumin alone. Therefore, this concentration was used for further experiments. In the complex protection experiment, the curcumin-Cu(II) complex further increased cell viability in comparison with the curcumin group. However, the protective effects of the curcumin-Zn(II) complex was lower 
than curcumin (Figure 1C). It indicated that the curcumin-Cu(II) complex had relatively stronger protective effects than curcumin or the curcumin-Zn(II) complex, and the 2:1 curcumin-Cu(II) complex exhibited the most significant protective effect.
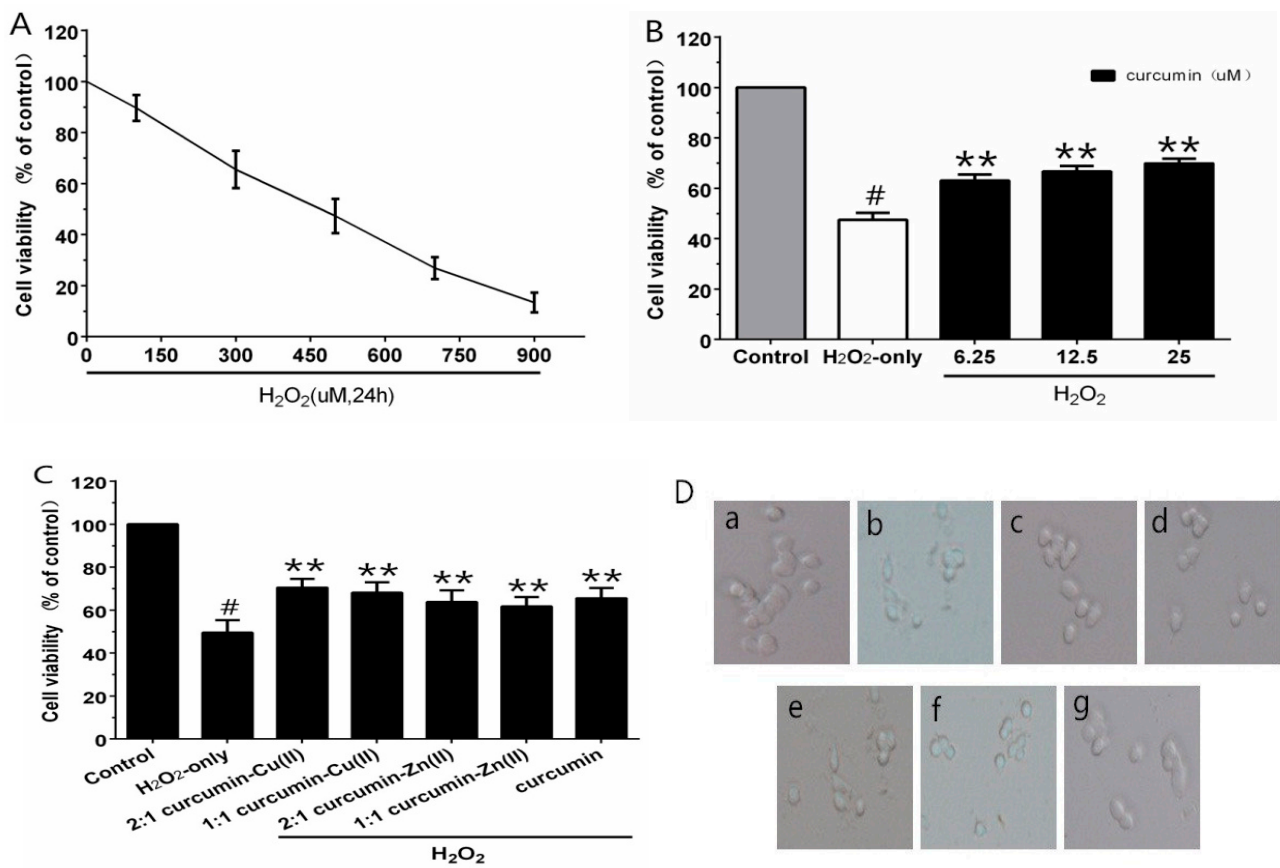

Figure 1. Curcumin and the complexes systems protected $\mathrm{PC} 12$ cells against $\mathrm{H}_{2} \mathrm{O}_{2}$-induced damage. Cytotoxic effects of $\mathrm{H}_{2} \mathrm{O}_{2}$ (A) on PC12 cells and the protective effects of curcumin (B) and the complexes (C) on $\mathrm{H}_{2} \mathrm{O}_{2}$-induced cytotoxicity to PC12 cells and morphological alteration (D). (a) control cells; (b) cells treated with $\mathrm{H}_{2} \mathrm{O}_{2}$ only; (c) cells pretreated with the 2:1 curcumin-Cu(II) complex system and co-treated with $\mathrm{H}_{2} \mathrm{O}_{2} ;$ (d) cells pretreated with the $1: 1$ curcumin- $\mathrm{Cu}$ (II) complex system and co-treated with $\mathrm{H}_{2} \mathrm{O}_{2}$; (e) cells pretreated with the 2:1 curcumin- $\mathrm{Zn}$ (II) complex system and co-treated with $\mathrm{H}_{2} \mathrm{O}_{2}$; (f) cells pretreated with the 1:1 curcumin- $\mathrm{Zn}(\mathrm{II})$ complexsystem and co-treated with $\mathrm{H}_{2} \mathrm{O}_{2} ;$ (g) cells pretreated with curcumin and co-treated with $\mathrm{H}_{2} \mathrm{O}_{2}$. ( ${ }^{\#} p<0.01$ versus control; ${ }^{*} p<0.05$ and ${ }^{* *} p<0.01$ versus $\mathrm{H}_{2} \mathrm{O}_{2}$-treated cells).

\subsection{Intracellular ROS Levels}

To verify whether curcumin and curcumin- $\mathrm{Cu}(\mathrm{II})$ or $-\mathrm{Zn}(\mathrm{II})$ complexes systems could prevent $\mathrm{H}_{2} \mathrm{O}_{2}$-induced ROS generation, the ROS levels were measured using the fluorescence probe DCFH-DA. Exposure of the cells to $500 \mu \mathrm{M} \mathrm{H}_{2} \mathrm{O}_{2}$ for $6 \mathrm{~h}$ significantly increased the intracellular ROS level, in comparison with control group (Figure 2A). PC12 cells pretreated with curcumin and curcumin-Cu(II) or $-\mathrm{Zn}$ (II) complexes system significantly reduced ROS levels. The 2:1 curcumin-Cu(II) complex exhibited more significant effects than curcumin and other complexes (Figure 2B). To further verify whether $\mathrm{H}_{2} \mathrm{O}_{2}$-induced cell death was via cell apoptosis, AV / PI staining was used to detect apoptotic cells. After treatment with $\mathrm{H}_{2} \mathrm{O}_{2}$, the nuclei of most PC12 cells were stained, indicating that cells were apoptotic (Figure 2C). The treatment of curcumin and curcumin-Cu(II) or - Zn(II) complexes systems on $\mathrm{H}_{2} \mathrm{O}_{2}$-treated PC12 cells displayed significantly reduced numbers of stained cells (Figure 2C), indicating that both curcumin and curcumin- $\mathrm{Cu}(\mathrm{II})$ or $-\mathrm{Zn}$ (II) complexes systems could attenuate cell apoptosis induced by $\mathrm{H}_{2} \mathrm{O}_{2}$. 

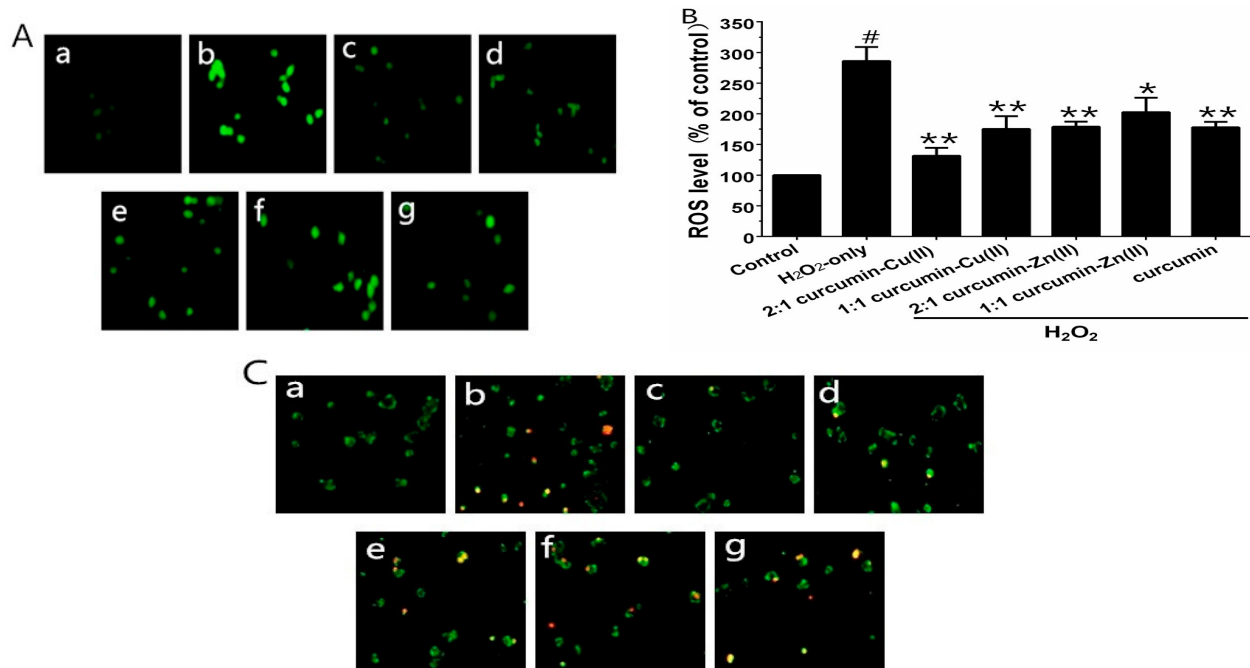

Figure 2. Inhibitory effects of curcumin and the complexes systems on the $\mathrm{H}_{2} \mathrm{O}_{2}$-induced reactive oxygen species (ROS) level and apoptotis in PC12 cells. (A) Representative images of 1-(4,5-dimethylthiazol-2-yl)-3,5-diphenylformazan (MTT) and 2',7'-dichlorofluorescindiacetate (DCFH-DA) staining in PC12 cells by fluorescent microscopy $(\times 100)$; (B) Intracellular reactive oxygen species (ROS) level; (C) Representative images of AV-FITC/PI staining under the microscope $(\times 100)$. (a) control cells; (b) cells treated with $\mathrm{H}_{2} \mathrm{O}_{2}$ only; (c) cells pretreated with the 2:1 curcumin- $\mathrm{Cu}$ (II) complex system and co-treated with $\mathrm{H}_{2} \mathrm{O}_{2} ;$ (d) cells pretreated with the $1: 1$ curcumin-Cu(II) complex system and co-treated with $\mathrm{H}_{2} \mathrm{O}_{2}$; (e) cells pretreated with the 2:1 curcumin- $\mathrm{Zn}$ (II) complex and co-treated with $\mathrm{H}_{2} \mathrm{O}_{2} ;$ (f) cells pretreated with the $1: 1$ curcumin- $\mathrm{Zn}$ (II) complex system and co-treated with $\mathrm{H}_{2} \mathrm{O}_{2}$; (g) cells pretreated with curcumin and co-treated with $\mathrm{H}_{2} \mathrm{O}_{2}$. ( ${ }^{\#} p<0.01$ versus control; ${ }^{*} p<0.05$ and ${ }^{* *} p<0.01$ versus $\mathrm{H}_{2} \mathrm{O}_{2}$-treated cells).

\subsection{MDA Levels and Antioxidant Enzyme Activities}

Exposure of PC12 cells to $\mathrm{H}_{2} \mathrm{O}_{2}$ caused an increase in the intracellular MDA level, and pretreatment with curcumin and curcumin-Cu(II) or $-\mathrm{Zn}$ (II) complexes systems obviously attenuated this increase (Figure 3A). Additionally, exposure of PC12 cells to $\mathrm{H}_{2} \mathrm{O}_{2}$ caused a decrease in the activities of SOD, CAT and GSH-Px (Figure 3B-D). Pretreatment with curcumin and curcumin-Cu(II) or - Zn(II) complexes systems significantly attenuated the changes in CAT, SOD and GSH-Px activities induced by $\mathrm{H}_{2} \mathrm{O}_{2}$, and the protective effects of the curcumin-Cu(II) complex system were stronger than curcumin or the curcumin-Zn(II) complex system.
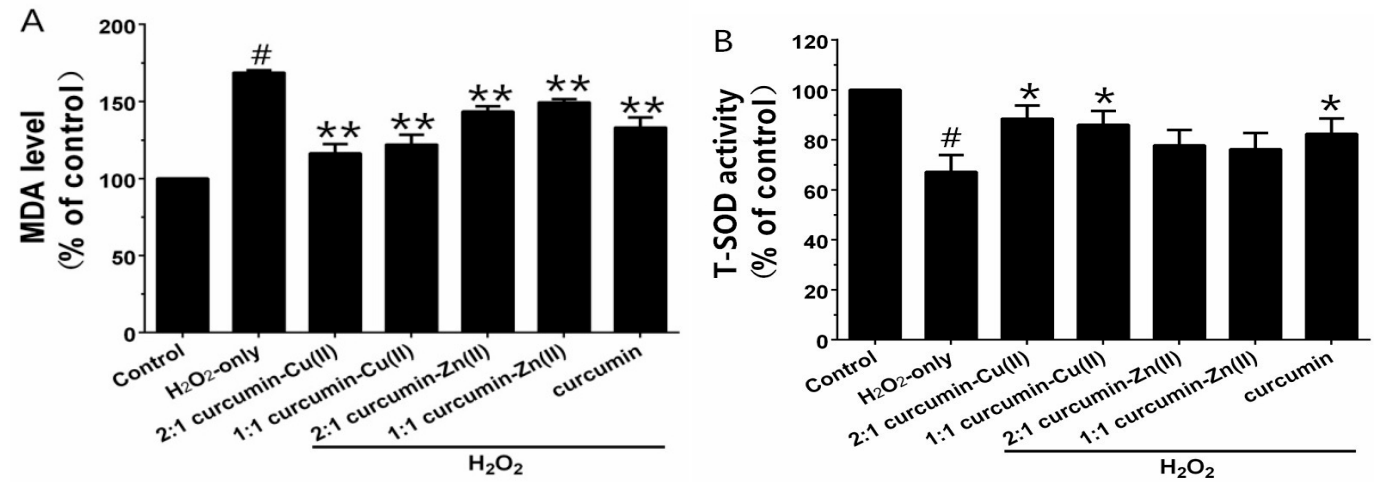

Figure 3. Cont. 

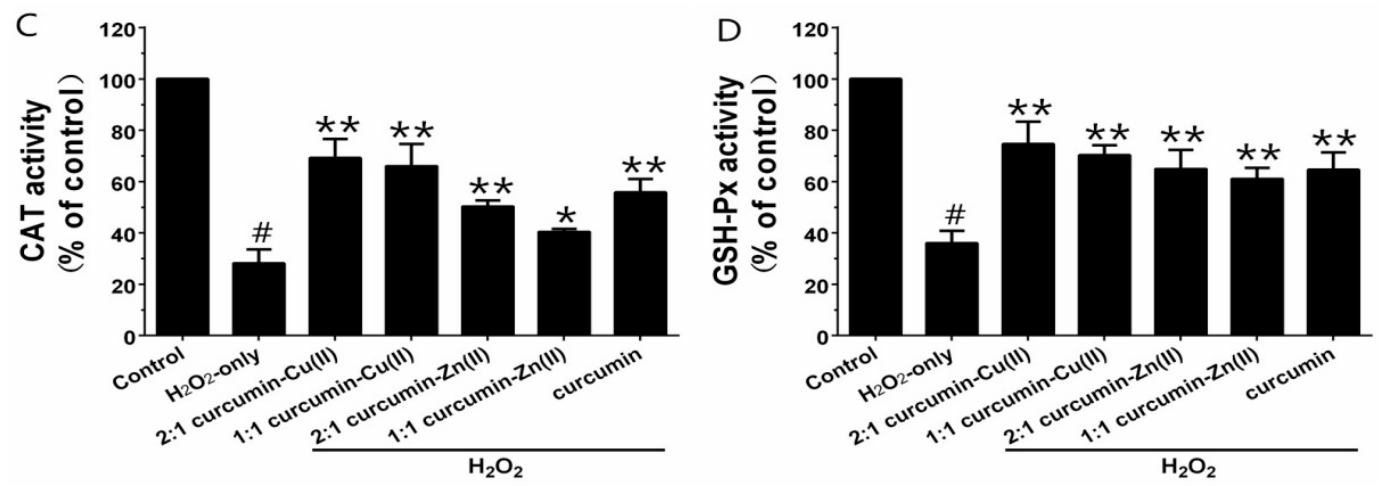

Figure 3. Effects of curcumin and the complexes on the malondialdehyde (MDA) level (A) and the activities of total superoxide dismutase (SOD) (B); catalase (CAT) (C) and glutathione peroxidase (GSH-Px) (D) in PC12 cells. PC12 cells were pretreated with curcumin and the complexes for $0.5 \mathrm{~h}$ before being exposed to $500 \mu \mathrm{M} \mathrm{H}_{2} \mathrm{O}_{2}$ for $6 \mathrm{~h}$. ( ${ }^{\#} p<0.01$ versus control; ${ }^{*} p<0.05$ and ${ }^{* *} p<0.01$ versus $\mathrm{H}_{2} \mathrm{O}_{2}$-treated cells).

\subsection{Caspase-3 and Caspase-9 Activities}

Caspase- 3 and -9 are the key executive proteins related to apoptosis. As shown in Figure 4, $\mathrm{H}_{2} \mathrm{O}_{2}$ obviously increased caspase- 3 and -9 activities and pretreatment with curcumin and curcumin- $\mathrm{Cu}$ (II) or $-\mathrm{Zn}$ (II) complexes attenuated the increases. The effect of the 2:1 curcumin-Cu(II) complex was the most significant-it decreased caspase-3 activity from $137.63 \pm 6.8 \%$ to $106.37 \pm 5.05 \%$ and caspase- 9 activity from $143.93 \pm 1.56 \%$ to $115.83 \pm 5.08 \%$.
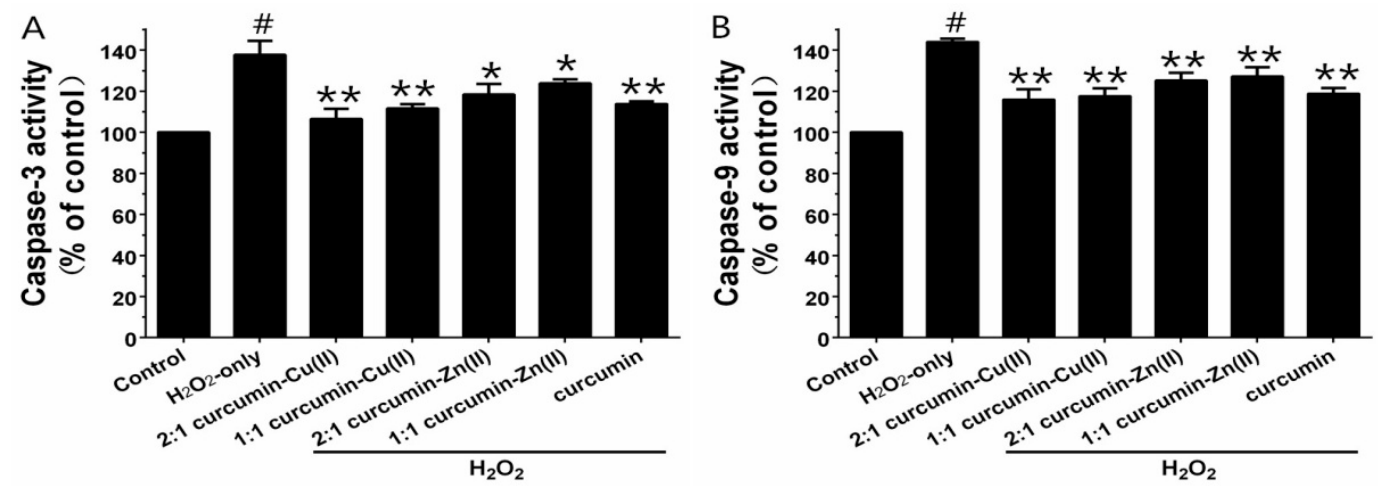

Figure 4. Effects of curcumin and the complexes systems on caspase-3 (A) and -9 (B) activity in $\mathrm{H}_{2} \mathrm{O}_{2}$-induced PC12 cells. Cells were pretreated with curcumin and the complexes systems for $0.5 \mathrm{~h}$ before being exposed to $500 \mu \mathrm{M} \mathrm{H}_{2} \mathrm{O}_{2}$ for $6 \mathrm{~h}$. Caspase- 3 and -9 activities were determined using a commercial kit, in accordance with the instructions of the manufacturer. ( ${ }^{\#} p<0.01$ versus control; ${ }^{*} p<0.05$ and ${ }^{* *} p<0.01$ versus $\mathrm{H}_{2} \mathrm{O}_{2}$-treated cells).

\subsection{Bcl-2/Bax Ratio and NF- $\kappa B$ p65 Levels}

The Bcl-2/Bax ratio is an important factor in most mitochondria apoptotic proceedings. As shown in Figure 5A, exposing PC12 cells to $\mathrm{H}_{2} \mathrm{O}_{2}$ caused a significant decrease in the Bcl-2/Bax ratio, which was reversed by pretreatment with curcumin and curcumin- $\mathrm{Cu}(\mathrm{II})$ or $-\mathrm{Zn}$ (II) complexes systems. NF- $k B$ is one of the major anti-apoptotic factors induced by ROS [29]. NF- $k B$ is also regulated by various apoptotic stimuli or inhibitors. As shown in Figure 5B, Western blot results showed that p65 expression was increased in the presence of $\mathrm{H}_{2} \mathrm{O}_{2}$, while pretreatment with curcumin and curcumin- $\mathrm{Cu}$ (II) or $-\mathrm{Zn}$ (II) complexes systems significantly decreased the expression of p65 induced 
by $\mathrm{H}_{2} \mathrm{O}_{2}$. The effect of the 2:1 curcumin-Cu(II) complex system was stronger than curcumin or the other complexes.

A

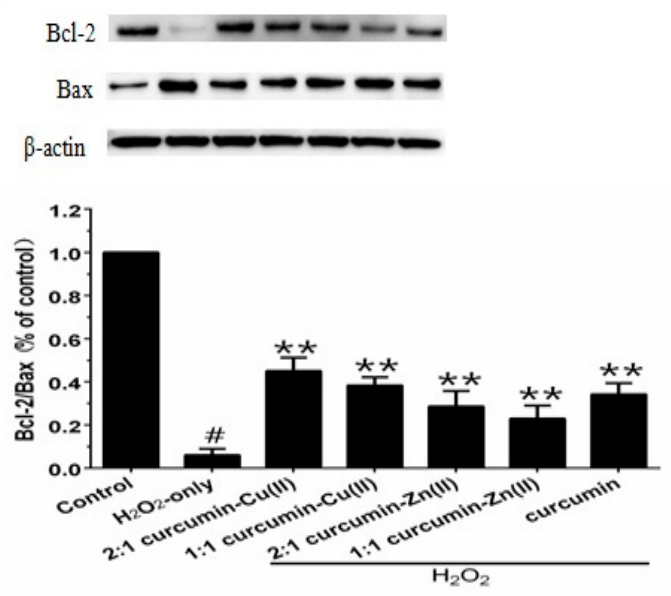

B

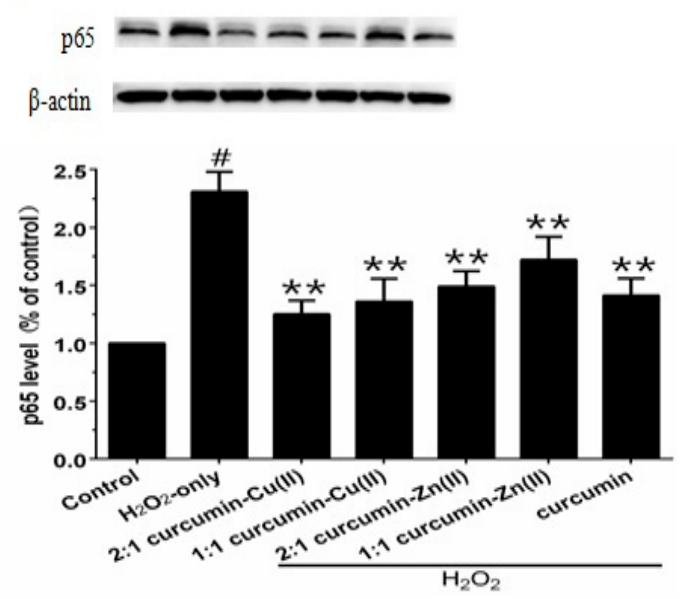

Figure 5. Effects of curcumin and the complexes system on the ratios of Bcl-2/Bax and p65 levels in PC12 cells. The PC12 cells were pretreated with curcumin and the complexes for $0.5 \mathrm{~h}$ and then exposed to $500 \mu \mathrm{M} \mathrm{H}_{2} \mathrm{O}_{2}$ for $12 \mathrm{~h}$. (A) The expression of Bcl-2/Bax, $\beta$-actin was used for normalization and verification of protein loading, $\mathrm{Bcl}-2$ and $\mathrm{Bax}$ in control, $\mathrm{H}_{2} \mathrm{O}_{2}$, curcumin and the complexes systems treatments and $\beta$-actin representations of the ratios of Bcl-2/Bax; (B) Following the same treatment, the p65 levels were identified. Data are shown as mean $\pm \operatorname{SD}(n=3)$. $\left({ }^{\#} p<0.01\right.$ versus control; ${ }^{* *} p<0.01$ versus $\mathrm{H}_{2} \mathrm{O}_{2}$-treated cells).

\section{Discussion}

Screening multi-function drugs from natural products to treat AD has gained much interest in recent years [26,36,37]. Curcumin is an intensively investigated natural polyphenol with antioxidant activity, which can scavenge various ROS and reactive nitrogen species (RNS), and inhibit lipid peroxidation [19]. Curcumin has been found to be a metal ion chelator and can bind various metal ions. It is interesting to explore whether metal ion complexes of curcumin possess neuroprotective effects, which will endow curcumin another advantage against AD. The present study revealed that curcumin can inhibit $\mathrm{H}_{2} \mathrm{O}_{2}$-induced injury in neuronal PC12 cells, which is consistent with previous studies $[29,38,39]$. The effective concentration of curcumin employed in the present study was lower than that in the study of Siddiqui et al., which may arise from the different concentrations of employed $\mathrm{H}_{2} \mathrm{O}_{2}$ and a dose-dependent vulnerability of $\mathrm{PC} 12$ cells against $\mathrm{H}_{2} \mathrm{O}_{2}$ exposure [39]. Both curcumin- $\mathrm{Cu}(\mathrm{II})$ and $-\mathrm{Zn}(\mathrm{II})$ complexes were found to possess neuroprotective effects on PC12 cells, and the protective effects of the curcumin-Cu(II) complexes were relatively stronger than parent curcumin. The significant neuroprotective effects of curcumin-Cu(II) complexes may arise from the SOD-like activities of curcumin-Cu(II) complexes [21-23]. Curcumin-Cu(II) and - $\mathrm{Zn}$ (II) complexes significantly increased the activities of antioxidant enzymes, including SOD, CAT and GSH, and attenuated the $\mathrm{H}_{2} \mathrm{O}_{2}$-induced increase in MDA levels and caspase- 3 and caspase- 9 activities in PC12 cells. Previous studies have reported that many genes are involved in cell apoptosis, such as Bcl-2 and Bax genes [40]. In our study, pretreatment with curcumin and curcumin-Cu(II) or - $\mathrm{Zn}$ (II) complexes upregulated the expression of anti-apoptotic protein $\mathrm{Bcl}-2$, and down-regulated the expression of pro-apoptotic protein $\mathrm{Bax}$, indicating that curcumin and curcumin- $\mathrm{Cu}$ (II) or $-\mathrm{Zn}$ (II) complexes systems inhibited cell apoptosis, via upregulating the Bcl-2/Bax pathway. NF- $\mathrm{KB}$ acts as an important anti-apoptotic factor and it was demonstrated that the link between oxidative stress and NF- $\mathrm{KB}$ mainly arises from the inhibition of NF- $\mathrm{kB}$ activation by many antioxidants [41,42]. Our study indicated that curcumin and curcumin- $\mathrm{Cu}$ (II) or $-\mathrm{Zn}$ (II) complexes inhibit cell apoptosis via downregulating the 
NF- $\mathrm{kB}$ pathway, which is consistent with previous studies [28,43]. However, curcumin was reported to have an extremely poor bioavailability, which makes its pharmacology difficult to be fully elucidated and also hampers its clinical applications. In view of its low stability [44,45], our previous studies proposed that the bioactive degradation products of curcumin should contribute to in its diverse pharmacological effects $[25,46,47]$. The degradation products retain the main functional groups of curucmin and exhibit similar biological activities and mechanisms as parent curcumin to combat AD, including antioxidants, $A \beta$ fibril formation-, and enzyme-inhibiting activities $[25,46]$. Additionally, many strategies have been used to improve the bioavailability of curcumin [48]. For instance, it was found that the application of adjuvants, like piperine, can significantly improve the bioavailability of curcumin [49].

\section{Conclusions}

To summarize, the present findings suggest that metal complexes of curcumin, especially curcumin- $\mathrm{Cu}(\mathrm{II})$, exhibit strong neuroprotective effects on neuronal PC12 cells. In view of the antioxidant and metal ion-chelating activities of curcumin, the neuroprotective effect of its metal complexes indicates the great advantages of curcumin as a promising anti-AD agent. In addition, it has been demonstrated that curcumin could inhibit $A \beta$ aggregation and ameliorate $A \beta$-induced toxicity $[25,50-52]$, and inhibit acetylcholinesterase activity $[25,53]$. Thus, the potentials of curcumin as a natural agent to combat $\mathrm{AD}$ deserve more preclinical and clinical studies.

Acknowledgments: This work was supported by the Shandong Provincial Science Foundation for Distinguished Young Scholars (Grant No. JQ201508) and in part by National Natural Science Foundation of China (Grant No. 31370745) and the National Science and Technology Major Projects of New Drugs (Grant No. 2015ZX09102015).

Author Contributions: L.S. and H.-F.J. conceived and designed the experiments; F.-S.Y. and J.-L.S. performed the experiments; F.-S.Y., W.-H.X., H.-F.J. and L.S. analyzed the data; F.-S.Y., L.S. and H.-F.J. wrote the paper.

Conflicts of Interest: The authors declare no conflict of interest. The founding sponsors had no role in the design of the study; in the collection, analyses, or interpretation of data; in the writing of the manuscript, and in the decision to publish the results.

\section{References}

1. Burns, A.; Iliffe, S. Alzheimer's disease. BMJ 2009, 338, b158. [CrossRef] [PubMed]

2. Brookmeyer, R.; Johnson, E.; Ziegler-Graham, K.; Arrighi, H.M. Forecasting the global burden of Alzheimer's disease. Alzheimers Dement. 2007, 3, 186-191. [CrossRef] [PubMed]

3. Querfurth, H.W.; LaFerla, F.M. Alzheimer's disease. N. Engl. J. Med. 2010, 362, 329-344. [CrossRef] [PubMed]

4. Barnham, K.J.; Masters, C.L.; Bush, A.I. Neurodegenerative diseases and oxidative stress. Nat. Rev. Drug Discov. 2004, 3, 205-214. [CrossRef] [PubMed]

5. Reddy, V.P.; Zhu, X.; Perry, G.; Smith, M.A. Oxidative stress in diabetes and Alzheimer's disease. J. Alzheimers Dis. 2009, 16, 763-774. [CrossRef] [PubMed]

6. Agostinho, P.; Cunha, R.A.; Oliveira, C. Neuroinflammation, oxidative stress and the pathogenesis of Alzheimer's disease. Curr. Pharm. Des. 2010, 16, 2766-2778. [CrossRef] [PubMed]

7. Lin, M.T.; Beal, M.F. Mitochondrial dysfunction and oxidative stress in neurodegenerative diseases. Nature 2006, 443, 787-795. [CrossRef] [PubMed]

8. Eskici, G.; Axelsen, P.H. Copper and oxidative stress in the pathogenesis of Alzheimer's disease. Biochemistry 2012, 51, 6289-6311. [CrossRef] [PubMed]

9. Bush, A.I. The Metallobiology of Alzheimer's Disease. Trends Neurosci. 2003, 26, 207-214. [CrossRef]

10. Waggoner, D.J.; Bartnikas, T.B.; Gitlin, J.D. The Role of Copper in Neurodegenerative Disease. Neurobiol. Dis. 1999, 6, 221-230. [CrossRef] [PubMed]

11. Robert, A.; Liu, Y.; Nguyen, M.; Meunier, B. Regulation of copper and iron homeostasis by metal chelators: A possible chemotherapy for Alzheimer's disease. Acc. Chem. Res. 2015, 48, 1332-1339. [CrossRef] [PubMed]

12. Kawada, H.; Kador, P.F. Orally Bioavailable Metal Chelators and Radical Scavengers: Multifunctional Antioxidants for the Coadjutant Treatment of Neurodegenerative Diseases. J. Med. Chem. 2015, 58, 8796-8805. [CrossRef] [PubMed] 
13. Crouch, P.J.; Barnham, K.J. Therapeutic redistribution of metal ions to treat Alzheimer's disease. Acc. Chem. Res. 2012, 45, 1604-1611. [CrossRef] [PubMed]

14. Agrawal, D.K.; Mishra, P.K. Curcumin and its analogues: Potential anticancer agents. Med. Res. Rev. 2010, 30, 818-860. [CrossRef] [PubMed]

15. Anand, P.; Thomas, S.G.; Kunnumakkara, A.B.; Sundaram, C.; Harikumar, K.B.; Sung, B.; Tharakan, S.T.; Misra, K.; Priyadarsini, I.K.; Rajasekharan, K.N.; et al. Biological activities of curcumin and its analogues (Congeners) made by man and Mother Nature. Biochem. Pharmacol. 2008, 76, 1590-1611. [CrossRef] [PubMed]

16. Aggarwal, B.B.; Sung, B. Pharmacological basis for the role of curcumin in chronic diseases: An age-old spice with modern targets. Trends Pharmacol. Sci. 2009, 30, 85-94. [CrossRef] [PubMed]

17. Zhou, H.; Beevers, C.S.; Huang, S. The targets of curcumin. Curr. Drug Targets 2011, 12, 332-347. [CrossRef] [PubMed]

18. Shen, L.; Ji, H.F. Theoretical study on physicochemical properties of curcumin. Spectrochim. Acta Mol. Biomol. Spectrosc. 2007, 67, 619-623. [CrossRef] [PubMed]

19. Menon, V.P.; Sudheer, A.R. Antioxidant and anti-inflammatory properties of curcumin. Adv. Exp. Med. Biol. 2007, 595, 105-125. [PubMed]

20. Baum, L.; $\mathrm{Ng}$, A. Curcumin interaction with copper and iron suggests one possible mechanism of action in Alzheimer's disease animal models. J. Alzheimers Dis. 2004, 6, 367-377. [CrossRef] [PubMed]

21. Barik, A.; Mishra, B.; Shen, L.; Mohan, H.; Kadam, R.M.; Dutta, S.; Zhang, H.Y.; Priyadarsini, K.I. Evaluation of a new copper(II)-curcumin complex as superoxide dismutase mimic and its free radical reactions. Free Radic. Biol. Med. 2005, 39, 811-822. [CrossRef] [PubMed]

22. Shen, L.; Zhang, H.Y.; Ji, H.F. A Theoretical study on $\mathrm{Cu}(\mathrm{II})$-chelating properties of curcumin and its implications for curcumin as a multipotent agent to combat Alzheimer's disease. J. Mol. Struct. Theochem. 2005, 757, 199-202. [CrossRef]

23. Barik, A.; Mishra, B.; Kunwar, A.; Kadam, R.M.; Shen, L.; Dutta, S.; Padhye, S.; Satpati, A.K.; Zhang, H.Y.; Indira Priyadarsini, K. Comparative study of copper(II)-curcumin complexes as superoxide dismutase mimics and free radical scavengers. Eur. J. Med. Chem. 2007, 42, 431-439. [CrossRef] [PubMed]

24. Tang, M.; Taghibiglou, C. The Mechanisms of Action of Curcumin in Alzheimer's Disease. J. Alzheimers Dis. 2017, 58, 1003-1016. [CrossRef] [PubMed]

25. Shen, L.; Liu, C.C.; An, C.Y.; Ji, H.F. How does curcumin work with poor bioavailability? Clues from experimental and theoretical studies. Sci. Rep. 2016, 6, 20872. [CrossRef] [PubMed]

26. Ji, H.F.; Zhang, H.Y. Multipotent natural agents to combat Alzheimer's disease. Functional spectrum and structural features. Acta Pharmacol. Sin. 2008, 29, 143-151. [CrossRef] [PubMed]

27. Westerink, R.H.S.; Ewing, A.G. The PC12 cell as model for neurosecretion. Acta Physiol. 2008, 192, $273-285$. [CrossRef] [PubMed]

28. Tusi, S.K.; Ansari, N.; Amini, M.; Amirabad, A.D.; Shafiee, A.; Khodagholi, F. Attenuation of NF- $\mathrm{kB}$ and activation of Nrf2 signaling by 1,2,4-triazine derivatives, protects neuron-like PC12 cells against apoptosis. Apoptosis 2010, 15, 738-751. [CrossRef] [PubMed]

29. Park, S.Y.; Kim, H.S.; Cho, E.K.; Kwon, B.Y.; Phark, S.; Hwang, K.W.; Sul, D. Curcumin protected PC12 cells against beta-amyloid-induced toxicity through the inhibition of oxidative damage and tau hyperphosphorylation. Food Chem. Toxicol. 2008, 46, 2881-2887. [CrossRef] [PubMed]

30. Lee, S.Y.; Lee, J.W.; Lee, H.; Yoo, H.S.; Yun, Y.P.; Oh, K.W.; Ha, T.Y.; Hong, J.T. Inhibitory effect of green tea extract on beta-amyloid-induced PC12 cell death by inhibition of the activation of NF-kappaB and ERK/p38 MAP kinase pathway through antioxidant mechanisms. Brain Res. Mol. Brain Res. 2005, 140, 45-54. [CrossRef] [PubMed]

31. Hoi, C.P.; Ho, Y.P.; Baum, L.; Chow, A.H. Neuroprotective effect of honokiol and magnolol, compounds from Magnolia officinalis, on beta-amyloid-induced toxicity in PC12 cells. Phytother. Res. 2010, 24, 1538-1542. [CrossRef] [PubMed]

32. Li, X. Improved pyrogallol autoxidation method: A reliable and cheap superoxide-scavenging assay suitable for all antioxidants. J. Agric. Food Chem. 2012, 60, 6418-6424. [CrossRef] [PubMed]

33. Mosmann, T. Rapid colorimetric assay for cellular growth and survival: Application to proliferation and cytotoxicity assays. J. Immunol. Methods 1983, 65, 55-63. [CrossRef] 
34. Nahar, K.; Hasanuzzaman, M.; Alam, M.M.; Fujita, M. Roles of exogenous glutathione in antioxidant defense system and methylglyoxal detoxification during salt stress in mung bean. Biol. Plant. 2015, 59, 745-756. [CrossRef]

35. Bradford, M.M. A rapid and sensitive method for the quantitation of microgram quantities of protein utilizing the principle of protein-dye binding. Anal. Biochem. 1976, 72, 248-254. [CrossRef]

36. Ji, H.F.; Li, X.J.; Zhang, H.Y. Natural products and drug discovery. Can thousands of years of ancient medical knowledge lead us to new and powerful drug combinations in the fight against cancer and dementia? EMBO Rep. 2009, 10, 194-200. [CrossRef] [PubMed]

37. Russo, P.; Frustaci, A.; Del Bufalo, A.; Fini, M.; Cesario, A. Multitarget drugs of plants origin acting on Alzheimer's disease. Curr. Med. Chem. 2013, 20, 1686-1693. [CrossRef] [PubMed]

38. Kim, D.S.; Park, S.Y.; Kim, J.K. Curcuminoids from Curcuma longa L. (Zingiberaceae) that protect PC12 rat pheochromocytoma and normal human umbilical vein endothelial cells from betaA(1-42) insult. Neurosci. Lett. 2001, 303, 57-61. [CrossRef]

39. Siddiqui, M.A.; Kashyap, M.P.; Kumar, V.; Tripathi, V.K.; Khanna, V.K.; Yadav, S.; Pant, A.B. Differential protection of pre-, co- and post-treatment of curcumin against hydrogen peroxide in PC12 cells. Hum. Exp. Toxicol. 2011, 30, 192-198. [CrossRef] [PubMed]

40. Deng, J.S.; Lee, S.D.; Kuo, W.W. Anti-apoptotic and pro-survival effect of protocatechuic acid on hypertensive hearts. Chem. Biol. Interact. 2014, 209, 77-84. [CrossRef] [PubMed]

41. Kalmar, B.; Greensmith, L. Induction of heat shock proteins for protection against oxidative stress. Adv. Drug Deliv. Rev. 2009, 61, 310-318. [CrossRef] [PubMed]

42. Feinstein, D.L.; Galea, E.; Reis, D.J. Suppression of glial nitric oxide synthase induction by heat shock: Effects on proteolytic degradation of IkappaB-alpha. Nitric Oxide 1997, 1, 167-176. [CrossRef] [PubMed]

43. Jang, J.H.; Surh, Y.J. Beta-amyloid-induced apoptosis is associated with cyclooxygenase-2 up-regulation via the mitogen-activated protein kinase-NF-kappaB signaling pathway. Free Radic. Biol. Med. 2005, 38, 1604-1613. [CrossRef] [PubMed]

44. Wang, Y.J.; Pan, M.H.; Cheng, A.L.; Lin, L.I.; Ho, Y.S.; Hsieh, C.Y.; Lin, J.K. Stability of curcumin in buffer solutions and characterization of its degradation products. J. Pharm. Biomed. Anal. 1997, 15, 1867-1876. [CrossRef]

45. Lin, J.K.; Pan, M.H.; Lin-Shiau, S.Y. Recent studies on the biofunctions and biotransformations of curcumin. Biofactors 2000, 13, 153-158. [CrossRef] [PubMed]

46. Shen, L.; Ji, H.F. The pharmacology of curcumin: Is it the degradation products? Trends Mol. Med. 2012, 18, 138-144. [CrossRef] [PubMed]

47. Ji, H.F.; Shen, L. Can improving bioavailability improve the bioactivity of curcumin? Trends Pharmacol. Sci. 2014, 35, 265-266. [CrossRef] [PubMed]

48. Anand, P.; Kunnumakkara, A.B.; Newman, R.A.; Aggarwal, B.B. Bioavailability of curcumin: Problems and promises. Mol. Pharm. 2007, 4, 807-818. [CrossRef] [PubMed]

49. Shoba, G.; Joy, D.; Joseph, T.; Majeed, M.; Rajendran, R.; Srinivas, P.S. Influence of piperine on the pharmacokinetics of curcumin in animals and human volunteers. Planta Med. 1998, 64, 353-356. [CrossRef] [PubMed]

50. Thapa, A.; Jett, S.D.; Chi, E.Y. Curcumin Attenuates Amyloid- $\beta$ Aggregate Toxicity and Modulates Amyloid- $\beta$ Aggregation Pathway. ACS Chem. Neurosci. 2016, 7, 56-68. [CrossRef] [PubMed]

51. Yanagisawa, D.; Taguchi, H.; Yamamoto, A.; Shirai, N.; Hirao, K.; Tooyama, I. Curcuminoid binds to amyloid-b1-42 oligomer and fibril. J. Alzheimers Dis. 2011, 24, 33-42. [PubMed]

52. Yang, F.; Lim, G.P.; Begum, A.N.; Ubeda, O.J.; Simmons, M.R.; Ambegaokar, S.S.; Chen, P.P.; Kayed, R.; Glabe, C.G.; Frautschy, S.A.; et al. Curcumin inhibits formation of amyloid beta oligomers and fibrils, binds plaques, and reduces amyloid in vivo. J. Biol. Chem. 2005, 280, 5892-5901. [CrossRef] [PubMed]

53. Ahmed, T.; Gilani, A.H. Inhibitory effect of curcuminoids on acetylcholinesterase activity and attenuation of scopolamine-induced amnesia may explain medicinal use of turmeric in Alzheimer's disease. Pharmacol. Biochem. Behav. 2009, 91, 554-559. [CrossRef] [PubMed] 